NASA Technical Memorandum 106047

AIAA-93-2176

\title{
Development and Use of Hydrogen-Air Torches in an Altitude Facility
}

Roy A. Lottig National Aeronautics and Space Administration

Lewis Research Center

Cleveland, Ohio

and

Gary T. Huber

Sverdrup Technology, Inc.

Lewis Research Center Group

Brook Park, Ohio

Prepared for the

29th Joint Propulsion Conference and Exhibit

cosponsored by the AIAA, SAE, ASME, and ASEE

Monterey, California, June 28-30, 1993 


\title{
DEVELOPMENT AND USE OF HYDROGEN-AIR TORCHES IN AN ALTITUDE FACILITY
}

\author{
Roy A. Lottig \\ National Aeronautics and Space Administration \\ Lewis Research Center \\ Cleveland, Ohio $\mathbf{4 4 1 3 5}$ \\ Gary T. Huber \\ Sverdrup Technology, Inc. \\ Lewis Research Center Group \\ Brook Park, Ohio 44142
}

\begin{abstract}
A hydrogen-air ignition torch concept that had been used successfully in two rocket engine test facilities to consume excess hydrogen in their exhausters at atmospheric conditions was experimentally evaluated and developed in an altitude test facility at NASA Lewis Research Center. The idea was to use several of these torches in conjunction with hydrogen detectors and dilution air to prevent excess accumulation of unburned hydrogen or mixtures of hydrogen and air exceeding the sea-level lower flammability limit in the altitude facility exhaust system during hydrogen-fueled propulsion system tests. The torches were evaluated for a range of fuel-to-air ratios from 0.09 to 0.39 and for a range of exit diameters from 19/64 to $49 / 64$ in. From the results of these tests a torch geometry and a fuel-to-air ratio were selected that produced a reasonably sized torch exhaust flame for consumption of unburned hydrogen at altitude pressures from sea level to 4 psia.
\end{abstract}

\section{Introduction}

The NASA Lewis Research Center Propulsion Systems Laboratory (PSL) altitude test facility was modified to support hypersonic propulsion research. The addition of high-energy gaseons makeup oxygen and two hydrogen fuel systems for an air hester and test article were part of this endeavor. During the PSL modifications a major worry was the disposition of unburned hydrogen in the facility and its exhaust system. For performance requirements air-breathing, hydrogen-fueled hypersonic engines run fuel rich. In addition, unburned hydrogen may be present because of a no-ignition condition, fitting leaks, or a ruptured hydrogen line. All of these excess hydrogen sources, if not handled properly, could cause hydrogen to accumulate in the exhaust ducts of the test facility and lead to an explosion with resultant injury to personnel or damage to the facility. Several methods can be used to safeguard against such a catastrophe: (1) use sound engineering principles in designing the system, (2) closely monitor the system for any anomalies, (3) dilute any hydrogen in the exhaust system to prevent flammable or explosive mixtures, or (4) provide ignition sources in the exhaust system for safe consumption of any flammable mixtures that may occur.

NASA Lewis has gone to great lengths to use sound engineering in designing, fabricating, and installing oxygen and hydrogen holding and transfer systems for the PSL altitude test facility to prevent leaks or line breaks from occurring in the first place. ${ }^{111}$ The oxygen and hydrogen systems include pressure switches for detecting loss of operating pressures, and strategically located hydrogen sensors are used to monitor hydrogenair mixtures. Nitrogen or carbon dioxide could be added to the exhaust system as dilnents, but the amount required would make testing prohibitively costly because the facility usually operates continuously, up to 5 or 6 hours, during individual test periods. Combustion air and test cell cooling air are available for dilution, but the amount may not always be sufficient, for some operating or failure scenarios, to keep the hydrogen-air mixture in the exhaust system below the lower flammability limit. For this reason NASA Lewis chose to use hydrogen-air ignition torches and hydrogen detectors in conjunction with dilution air in order to prevent hydrogen-air mixtures from reaching the sea-level lower flammability limit. This limit was conservatively set at 4 percent hydrogen by volume in the exhaust ducts exiting PSL.

On the basis of this decision NASA Lewis entered upon a test program to evaluate and develop a hydrogen-air ignition torch system. The hydrogen-air torch tests were initiated at the PSL altitude facility by installing and evaluating the torch design used successfully at the NASA Lewis Rocket Engine Test Facility (RETF) and Combustion Research Laboratory (CRL) in their exhaust systems at atmospheric conditions. ${ }^{12}$ Immediately, in an altitude environment the torch tests in PSL uncovered difficulties and deficiencies that were not encountered at atmospheric conditions. Lighting the torch and generating a substantial exhaust flame were impossible when the altitude pressure decreased below 4 psia. Consequently, follow-on tests with torch 
modifications were required. This report presents the details of those efforts.

\section{Apparatus}

\section{$\underline{\text { PSL Facility }}$}

The hydrogen-air ignition torch evaluation and development tests were performed in the Propulsion Systems Laboratory (PSL) altitude test facility. Two test chambers are located in the PSL facility. Each test chamber is $24 \mathrm{ft}$ in diameter and approximately $39 \mathrm{ft}$ in length. Generally, some of the combustion air supplied to the test facility bypasses the test chamber while the remaining amount, conditioned to the desired stagnation pressure and temperature, enters the test article in a direct-connect mode. The test chamber in the meantime is evacuated to the desired altitude pressure. Exhaust gases from the test article, cooling air through the test chamber, and the bypassed combustion air are mixed downstream of the test chamber in the facility exhaust plenum.

One of the PSL altitude chambers (PSL-4) was modified to support hypersonic propulsion research (Fig. 1). The modifications included the addition of high-energy gaseous hydrogen fuel sources for the air heater and test article and a makeup gaseous oxygen system. When the facility is operating, the hydrogenfueled air heater produces vitiated air, and the makeup oxygen reestablishes the combustion gas oxygen content at 21 percent by volume before it enters the test article. The facility modifications also included the addition of hydrogen detectors and the ignition torch system.

\section{Hydrogen-Air Torches}

All hydrogen-air torches tested in PSL were similar in operational concept to the initial NASA Lewis RETF and CRL toreh shown in Figs. 2 and 3. The torches were fabricated of 304 stainless steel. The torch, shown schematically in Fig. 2, was supplied with air and hydrogen. The flows were controlled by choked orifices that were sized to produce an overall fuel-to-air (f/a) ratio that was hydrogen rich (the stoichiometric $f / a$ ratio for hydrogen-air mixtures is 0.0293 ). Some of the air cooled the combustion tube and eventually mixed with the burning combustion tube hydrogen-air mixture before exiting the torch. A standard automotive spark plug was used for the ignition source. Two closed-ballgrounded, Chromel-Alumel, type $\mathrm{K}$ thermocouples were spot welded to the exit end of each torch to monitor the ambient temperature near the exit flame. These thermocouples were used to indicate and monitor torch light-off and flame existence. Once the torch was lit, the ignition source was deenergized. The first torch tested, with the thermocouples installed, is shown in Fig. 3.

\section{Procedure}

After evaluating and selecting a hydrogen-air torch concept, the intent was to install three torches at the exit plane of the test article and four more farther downstream near the top of the PSL exhaust plenum, as shown in Fig. 4. Of the four torches in the exhaust plenum, two were located upstream of the primary cooler and penetrated the water jacket of this section; the other two were located near the exat of the spray cooler section. The three torches located at the test article discharge, or exhaust collector inlet, would be spaced circumferentially at $120^{\circ}$ intervals and would be installed so that their flames impinged on or penetrated the test article discharge flow. Figure 5 shows a schematic of the torch installation at the exhaust collector inlet location.

The exhaust collector inlet location was selected in an attempt to consume excess hydrogen as soon as possible, before it could accumalate in the exhaust plenum system. This location would be the most severe environment for torch operation. Here the test article exhaust and the test chamber cooling air enter the exhaust collector simultaneously, resulting in much higher velocities and disturbances than would be experienced in the exhaust plenum. If the torches would operate adequately in this region, it was thought, they would perform well in the exhaust plenum.

Each torch configuration installed at the exhanst collector inlet location was supplied from a regulated 125-psig air, 450-psig hydrogen system (Fig. 6). Flow rates were calculated from the torch choked-orifice areas and the supply pressures and temperatures. The torch flame size was monitored by the output of a lowintensity-light camera that was displayed on a television monitor and recorded on a video cassette recorder (VCR) in the facility control room. The size of the flame was estimated from a prerun calibration by using a scale that was placed at the discharge of the torch while it was viewed on a television monitor. Masking tape was placed on the monitor screen at various scale increments, providing a means for flame size estimations. For a given torch configuration the air or hydrogen supply pressures were varied over a wide range, producing variations in $\mathrm{f} / \mathrm{a}$ ratios. At each $\mathrm{f} / \mathrm{a}$ ratio, supply pressure and flow data were recorded and the flame size was monitored and recorded on the VCR. The goal was to generate a flame of sufficient size and velocity so that it would penetrate or at least impinge on the test article exhaust flow, thus theoretically providing an ignition source for the excess hydrogen. 


\section{Results and Discussion}

First Torch Tests

The first torch configuration tested was identical to the ones used in the atmospheric exhausts at the RETF and CRL facilities. For the initial tests the torch (Fig. 5) was mounted off the top of the exhaust collector inlet face plate section and pointed downward with a cooling shroud around it so that the torch itself could not be seen with the low-intensity-light camera. The shroud was installed because it was not known at this time how the torch would perform in an altitude environment. With the shroud, cooling air could be supplied around the torch and the flame could be contained to prevent possible damage to the exhaust collector hardware. For these tests an axial-flow fan engine, which was undergoing testing at this time, was the test article. It provided a high-velocity exhanst plume. The torch was fitted with hydrogen and air orifice diameters of 0.052 and 0.062 in., respectively, and had an exit diameter of 19/64 in. (Figs. 2 and 3). As at RETF and CRL the hydrogen was supplied to the torch at 55 psia and the air at 65 psia. This produced a flow rate of $0.0006 \mathrm{lb} / \mathrm{sec}$ for hydrogen and $0.0037 \mathrm{lb} / \mathrm{sec}$ for air. The overall $\mathrm{f} / \mathrm{a}$ ratio was approximately 0.16 .

The goal of this test was to demonstrate the torch operation, down to the operating ambient pressure of 2 psia that was envisioned for the PSL-4 hypersonic modification demonstration tests. Attempts to light the torch at 3 psia were unsuccessful. The test chamber pressure was increased, and a successful light was achieved at 8 psia, which thus became the ambient pressure for torch light-off in the future. A flame was visible after the torch was lit at 8 psia, but the flame became noticeably smaller as ambient pressure was gradually reduced. Below an ambient pressure of 4 psia a flame was no longer visible, but a glow was visible, indicating that the torch was still lit. As ambient pressure was increased above 4 psia, the flame again became distinct and was estimated to be about 5 in. long. Slight deviations from a hydrogen supply pressure of 55 psia and an air pressure of 65 psia were made with no apparent effect on torch performance. A thermocouple grid was then installed downstream of and in line with the torch to determine if the flame was present but not visible. The grid thermocouples showed no temperature rise during minor hydrogen and air supply pressure excursions. The thermocouples on the torch ranged from 1058 to $1568{ }^{\circ} \mathrm{R}$ with no discernible correlation between the temperature and any other variable.

At this point a NASA Lewis employee, Erwin Lezberg, who has had vast experience with hydrogen combustion, was consulted. He indicated that below an ambient pressure of about 4 psia hydrogen is extremely difficult to ignite and burn beyond a localized area. The flame from the initial torch test was probably being extinguished as soon as it exited the torch. This implied that even if a good flame could be obtained from the torch, there was no guarantee that a hydrogen accumulation passing the torch would ignite, or that if it did, the flame would propagate throughout the flammable mixture. This was not a good indication for the success of these torches at altitude conditions much above $30000 \mathrm{ft}$ ( 4 psia). At this point two decisions were made. The first was to limit testing in PSL-4 to an ambient pressure of approximately 5 psia. This would not create a problem as long as the test article exhanst nozzle remained choked. The second decision was to modify the torch design to see if performance (exit flame size) could be improved at an ambient pressure of 5 psia.

\section{Second Torch Tests}

The modifications to the torch that were required to improve performance at altitude were not readily apparent. The original RETF and CRL torch operated unchoked in those facilities. It was decided to fabricate another RETF torch but with a converging-diverging (C-D) exit nozzle having a throat diameter of 19/64 in. The torch would then be tested at unchoked, justchoked, and hard-choked (definitely choked) conditions. The hydrogen and air orifice diameters were changed to 0.067 and 0.060 in., respectively. The $f / a$ ratio would be varied from 0.09 to 0.185 for each operating condition by varying supply pressures. In order to compare the C-D torch test results with initial torch performance, the initial torch's hydrogen and air orifice diameters were changed to 0.067 and 0.060 in., respectively. This enabled the torch to be operated over the same range of test conditions as the C-D nozzle torch. The performance data bases for both could then be compared for the same operating conditions and be used to make judgments for future modifications. The torch shroud, which was found to be unnecessary, was removed in order to have an unobstructed view of the torches.

The test matrix that was performed on the initial exhaust collector torch with the constant exit diameter of $19 / 64$ in. started with an $f / a$ ratio of 0.185 . As this ratio was decreased, the flame lengthened until an $f / a$ ratio of 0.13 was reached. As the $\mathrm{f} / \mathrm{a}$ ratio was decreased further, the flame grew smaller and torch exit ambient temperatures rose. The trend was for the torch to run hotter as the $\mathrm{f} / \mathrm{a}$ ratio was leaned toward the stoichiometric value of 0.0293 , as was expected. The effect of torch total pressure (air-supply-side level), which controlled the unchoked, just-choked, and hard-choked conditions, was less noticeable. The maximum torch flame length was approximately 5 to 6 in. 
The C-D torch performance was similar to that of the constant-exit-diameter torch. For a given $\mathrm{f} / \mathrm{a}$ ratio and torch pressure level condition the C-D torch temperatures were slightly lower and the flame was slightly longer and noticeably wider. For this torch the flame was approximately 7 in. long, and the torch exit ambient temperatures were approximately $1600^{\circ} \mathrm{R}$. The consensus was that this flame from the $C-D$ torch was sufficient for the still-to-be-fabricated exhaust plenum torches. These torches, which were located at the top of the plenum, would have to extend through the water jacket of the exhaust plenum. Therefore, the torch body and the combustion tube had to be about 14 in. longer than those at the exhaust collector inlet location. The exhaust plenum velocities were expected to be considerably less than those at the exhaust collector inlet location, so that any hydrogen accumulations would pocket in the top of the exhaust plenum and burn there. In addition, adding 14 in. to the length of the C-D torch was expected to have no effect on torch performance. This opinion was shared by the author of Ref. 12 . However, it seemed that a longer flame would be required for the exhaust collector inlet location in order to get better flame impingement on or into the test article exhaust and thereby increase the chance of igniting any hydrogen passing by these flames.

\section{Third Torch Tests}

In order to acquire some data on how nozzle exit diameter affects flame size, the initial torch exit diameter wos enlarged from $19 / 64$ in. to $27 / 64$ in. This roughly doubled the exit area. So that this modified torch could be tested over the same range of $\mathrm{f} / \mathrm{a}$ ratios $(0.09$ to 0.185$)$ and the same conditions corresponding to unchoked, just choked, and hard choked, the hydrogen and air orifice diameters were enlarged to 0.1285 and 0.110 in., respectively. This torch, during the tests, also got hotter as the $\mathrm{f} / \mathrm{a}$ ratio was leaned, but the optimum flame occurred at the higher $\mathrm{f} / \mathrm{a}$ ratios of 0.15 to 0.185 . The flame on this torch was approximately 10 to 12 in. long, and the torch temperatures at the exit were roughly $1700^{\circ} \mathrm{R}$. This was an encouraging sign in that the flame was getting bigger while the hydrogen flow rate was still a very low $0.0020 \mathrm{lb} / \mathrm{sec}$.

\section{Fourth Torch Tests}

The first exhaust plenum torch, which was 14 in. longer than the exhaust collector torches, was fabricated (Fig. 7). This exhaust plenum torch had the same size C-D exhaust nozzle throat diameter and orifice diameters that were used to produce the 7-in.-long flame for an $f / a$ ratio of 0.13 when the torch was 14 in. shorter.
The 14-in.-longer exhaust plenum torch did not perform the same as it had earlier at an $f / a$ ratio of 0.13 . At this $\mathrm{f} / \mathrm{a}$ ratio the flame was not visible on the low-intensity-light camera. The $\mathrm{f} / \mathrm{a}$ ratio was then gradually reduced to 0.09 , and a flame roughly 6 to 7 in. long was produced. It was felt that the added length of the torch, with the longer air cooling passage, cooled the torch enough to require a lower (hotter) $\mathrm{f} / \mathrm{a}$ ratio to produce a visible flame. Some further thought was now required to determine what to do next with the exhaust plenum torches.

Meanwhile, because drilling out the 8.75-in.-long exhanst collector torch to an exit diameter of $27 / 64$ in. had significantly lengthened the flame, the thought was to further enlarge the exit diameter. To do this and keep a reasonable contraction ratio required fabricating more torches with the following modifications: (1) the torch body was changed from 1 -in. by 0.065 -in.-wall tubing to 1.50 -in. by 0.065 -in.-wall tubing, (2) the inner combustion tube diameter was changed from 0.75 in. to 1.25 in., (3) the exit diameter was enlarged to 19/32 in., (4) for easier starting, two holes, each with a diameter of $0.0625 \mathrm{in}$., were added to the end cap of the combustion tube to help mix the hydrogen with air before the mixture reached the spark plug, (5) the hydrogen and air orifice diameters were enlarged to 0.159 and 0.1495 in., respectively, see Fig. 8.

The new-size torches were tested from $\mathrm{f} / \mathrm{a}$ ratios of 0.12 to 0.185 , which had produced the best flame length (10 to 12 in.) earlier. However, the larger torch did not produce much of a visible flame and ran quite hot, with an exit temperature of $1800^{\circ} \mathrm{R}$. Varying the $\mathrm{f} / \mathrm{a}$ ratio from 0.12 to 0.185 had little effect on temperature or flame size. At this point the way to proceed with the torch modifications was not clear. Both the exhaust plenum and exhaust collector torch performance trends were not the same as in earlier tests.

\section{Fifth Torch Tests}

A decision was made to run three exhanst collector torches spaced $120^{\circ}$ apart during the fifth series of tests in order to begin examining how multiple flame inpingement would be affected by test article exhaust flow. During this series of tests the exhaust collector torches with exit diameters of $27 / 64$ and $19 / 32$ in. were initially tested. When the torch with the $19 / 32$-in. exit diameter was first lit, a noticeably bigger flame was present than had been achieved during the previous tests. The $\mathrm{f} / \mathrm{a}$ ratio was approximately 0.24 , a ratio that had not been tested prior to this. The f/a ratio was reduced slowly to 0.15 to repeat the earlier test conditions. The torch performance repeated its earlier behavior, with the flame disappearing as the $f / a$ ratio was 
reduced. When the $f / a$ ratio was increased back to 0.24 , the larger flame reappeared, and as the $f / a$ ratio was further increased to 0.28 , the flame grew larger. At this condition the flame was roughly $12 \mathrm{in.} \mathrm{long.}$

When the 27/64-in.-exit-diameter exhaust collector torches were lit, they followed the same trends in that increasing the f/a ratio produced a bigger flame. Again, because $\mathrm{f} / \mathrm{a}$ ratios greater than 0.185 had not been tested earlier at this exit diameter, data were not available for comparison.

One of the 19/32-in.-exit-diameter exhaust collector torches was then drilled out to an exit diameter of 49/64 in. in order to investigate this nozzle exit diameter size. This torch repeated the trend of bigger flames for higher $\mathrm{f} / \mathrm{a}$ ratios, with the biggest flame at an $\mathrm{f} / \mathrm{a}$ ratio of 0.39 . This condition produced a flame approximately 18 in. long and 4 in. wide. An added benefit of running the torches at a higher $\mathrm{f} / \mathrm{a}$ ratio was that the torch exit temperatures were averaging $1600^{\circ} \mathrm{R}$, which would lengthen torch life.

\section{Sixth Torch Tests}

Prior to these torch tests, hardware for demonstrating the PSL-4 facility hypersonic inodification capabilities had been installed, including the hot-pipe test article. The hot pipe was nothing more than a hollow flow duct having a fixed-geometry flow path integrated with a fixed-area exhaust nozzle. The test article was designated a hot pipe rather than a cold pipe because air heated to $2260^{\circ} \mathrm{R}$ or more would flow through it.

The exhaust collector and plenum torches, which were soon to be installed for the hypersonic modification tests, required some final evaluations on how they would perform with and without air flowing through the hot pipe. Three exhaust collector torches were installed circumferentially at $120^{\circ}$ intervals to impinge on the hotpipe exhaust flow. All three torches had 1.50-in.diameter torch bodies and 1.25-in.-diameter combustor tubes. All torch exit diameters were 49/64 in. The air and hydrogen orifice diameters were 0.1495 and 0.159 in., respectively (Fig. 9). These torch tests were performed without hot-pipe airflow but with a test cell cooling airflow of $80 \mathrm{lb} / \mathrm{sec}$.

All torches were lit successfully at an ambient pressure of 8 psia. Ambient pressure was reduced to 5 psia, and the torch $\mathrm{f} / \mathrm{a}$ ratios were set at 0.39 . All torches produced flames approximately $18 \mathrm{in.}$ long. When viewed from the facility periscope camera, which was located in the facility exhaust plenum and pointed upstream toward the test chamber, the flames were seen to reach to the centerline of the hot-pipe exhaust nozzle.
Further tests with the exhaust plenum torch were then performed. The hydrogen orifice diameter remained at 0.067 in., but the air orifice diameter was enlarged from 0.060 to $0.110 \mathrm{in}$. The object was to test the torch at higher $f / a$ ratios to determine if the exit flame would become larger as it had for the exhaust collector torches. $A$ higher $\mathrm{f} / \mathrm{a}$ ratio on this torch did not produce a bigger flame, but the exit thermocouples indicated that the torch ran cool. Again by lowering the f/a ratio to 0.09, a maximum flame length of approximately 7 in. was generated.

\section{Seventh (Final) Torch Tests}

The last exhanst collector torch test involved combustion airflow through the hot pipe. The three exhaust collector torches that had been run without combustion airflow were used again. After the torches were lit at $8 \mathrm{psia}$, the hydrogen and air operating pressures were set at 27.7 and 21.2 psia, respectively. This produced a hydrogen flow of $0.0027 \mathrm{lb} / \mathrm{sec}$ and an airflow of $0.0069 \mathrm{lb} / \mathrm{sec}$ to each torch, resulting in an overall $\mathrm{f} / \mathrm{a}$ ratio of 0.39 . The test cell cooling airflow was set at $80 \mathrm{lb} / \mathrm{sec}$. The flames of the torches did not meet at the hot-pipe centerline but were bent and spread out in the exhanst flow direction while definitely impinging on the hot-pipe exhaust flow. A visible flame was atill present to such an extent that it would probably light any flammable mixture of hydrogen and air.

The exhaust plenum torch was then tested again but without the hot-pipe flow because gas mixtures flowing past its flame in the exhaust plenum would be at a much lower velocity. The hydrogen and air orifices remained at 0.067 and 0.110 in., respectively, but the exit throat diameter had been drilled ont to $27 / 64$ in. in order to evaluate the effect on torch performance. This modification to the exheust plenum torch appeared to improve its performance in that at an operating overall $\mathrm{f} / \mathrm{a}$ ratio of 0.14 a flame approximately $8 \mathrm{in.}$ long was produced, and torch thermocouple temperatures were approximately $1300^{\circ} \mathrm{R}$. For this $\mathrm{f} / \mathrm{a}$ ratio the operating pressures were 53.2 psia for the hydrogen and $\mathbf{3 7 . 2}$ psia for the air, producing a hydrogen flow of $0.00093 \mathrm{lb} / \mathrm{sec}$ and an airflow of $0.0068 \mathrm{lb} / \mathrm{sec}$.

From the results of these tests it was felt that the exhaust collector and exhaust plenum final torch configurations would be adequate for their purpose of burning off flammable mixtures of hydrogen and air during the PSL-4 hypersonic modification demonstration tests. However, operational problems developed with the longer (22.75 in.) exhaust plenum torches. Combustor tube warpage, a burned-off combustor tube at the upstream cooling holes, and spark plug damage occurred. No such damage was experienced with the 
shorter (8.75 in.) exhaust collector torches. Apparently the longer exhaust plenum torches operated with much higher temperatures in the interior, where the hydrogenair initial combustion occurs, resulting in excessive thermal stresses and burnthrough. Because the long torch failed, a decision was made to use the shorter exhaust collector torches in the exhaust plenum. Stainless steel wells or buckets were designed to penetrate the 14-in.-thick water-cooling jacket of the exhaust plenum walls upstream of the primary cooler to accommodate the shorter exhaust collector torches. The feedthroughs at the exit of the spray cooler section were also shortened to utilize the shorter exhaust collector torches at this location.

\section{Concluding Remarks}

When the original 8.75-in.-long Rocket Engine Test Facility (RETF) and Combustion Research Laboratory (CRL) facility hydrogen-air torch concept with an exit diameter of 19/64 in. was first tested in the Propulsion Systems Laboratory (PSL) facility at an altitude pressure of 5 psia and a fuel-to-air ( $f / a)$ ratio of 0.16 , the exit flame was approximately 5 in. long. The torch performance at an altitude pressure of 5 psia was improved by enlarging the torch body while maintaining its 8.75-in. length, increasing the $\mathrm{f} / \mathrm{a}$ ratio to 0.39 , and enlarging the exit diameter to $49 / 64$ in. With these modifications the torch exit flame for the exhaust collector location increased to $18 \mathrm{in}$. in length and about 4 in. in width.

Starting with the original 8.75-in.-long RETF and CRL torch concept a new torch, which was 14 in. longer so that it could penetrate the water-cooling jacket of the PSL exhaust plenum, was developed. It performed better in that the flame was roughly 8 in. long compared with the 5-in. flame of the original RETF and CRL torch. This wes accomplished by enlarging the torch exit diameter from 19/64 to $27 / 64$ in. and decreasing the f/a ratio from 0.16 to 0.14 . However, exhaust plenum torch internal failures developed during their operation, apparently due to excessive internal combustion temperatures. Thus, a decision was made to replace them with the shorter (8.75 in.), trouble-free, final exhaust collector torch concept.

The hydrogen-air torches in conjunction with hydrogen detectors and dilution air, were a cost-effective and efficient means of negating the possiblity of an explosion in the exhaust ducts of the PSL altitude facility. Because of the torches' welded plate-and-tube construction, they were simple to manufacture, were easy to monitor and maintain, and performed well at altitude pressures from sea level to 4 psia.

\section{References}

1. Occupational Safety and Health Standards, Title 29, Code of Federal Regulations, Pt. 1910.103: "Hydrogen," U.S. Department of Labor, 1990.

2. Occupational Safety and Health Standards, Title 29, Code of Federal Regulations, Pt. 1910.104: "Oxygen," U.S. Department of Labor, 1990.

3. American National Standards Institute/American Society of Mechanical Engineers, "Power Piping, Cryogenic Piping Systems," ANSI/ASME B31.1, 1990.

4. American Society of Mechanical Engineers, ASME Boiler and Pressure Vessel Code, Sec. VIII: "Pressure Vessels, ${ }^{\circ}$ Div. 1. ASME, 1989.

5. Bond, A.C., et al., "Design Guide for High Pressure Oxygen Systems," NASA RP-1113, 1983.

6. Banakitis, H., and Schueller, C.F., "ASRDI Oxygen Technology Survey," Vol. 2: "Cleaning Requirements, Procedures, and Verification Techniques," NASA SP-3072, 1972.

7. Schmidt, H.W., and Forney, D.E., "ASRDI Oxygen Technology Survey," Vol. 9: “Oxygen Systems Engineering Review," NASA SP-3090, 1975.

8. National Fire Protection Association, "Bulk Oxygen Systems at Consumer Sites," NFPA-50, Quincy, MA, 1990.

9. National Fire Protection Association, "Standard for Gaseous Hydrogen Systems at Consumer Sites," NFPA-50A, Quincy, MA, 1990.

10. National Fire Protection Association, "National Electric Code (NEC)," NFPA-70, Quincy, MA, 1990.

11. Graham, R., and $O^{\prime}$ Connor, K., eds., Lewis Safety Manual, NASA TM-104438, 1992.

12. Repas, G.A., "Hydrogen-Air Ignition Torch," NASA TM-88882, 1986. 


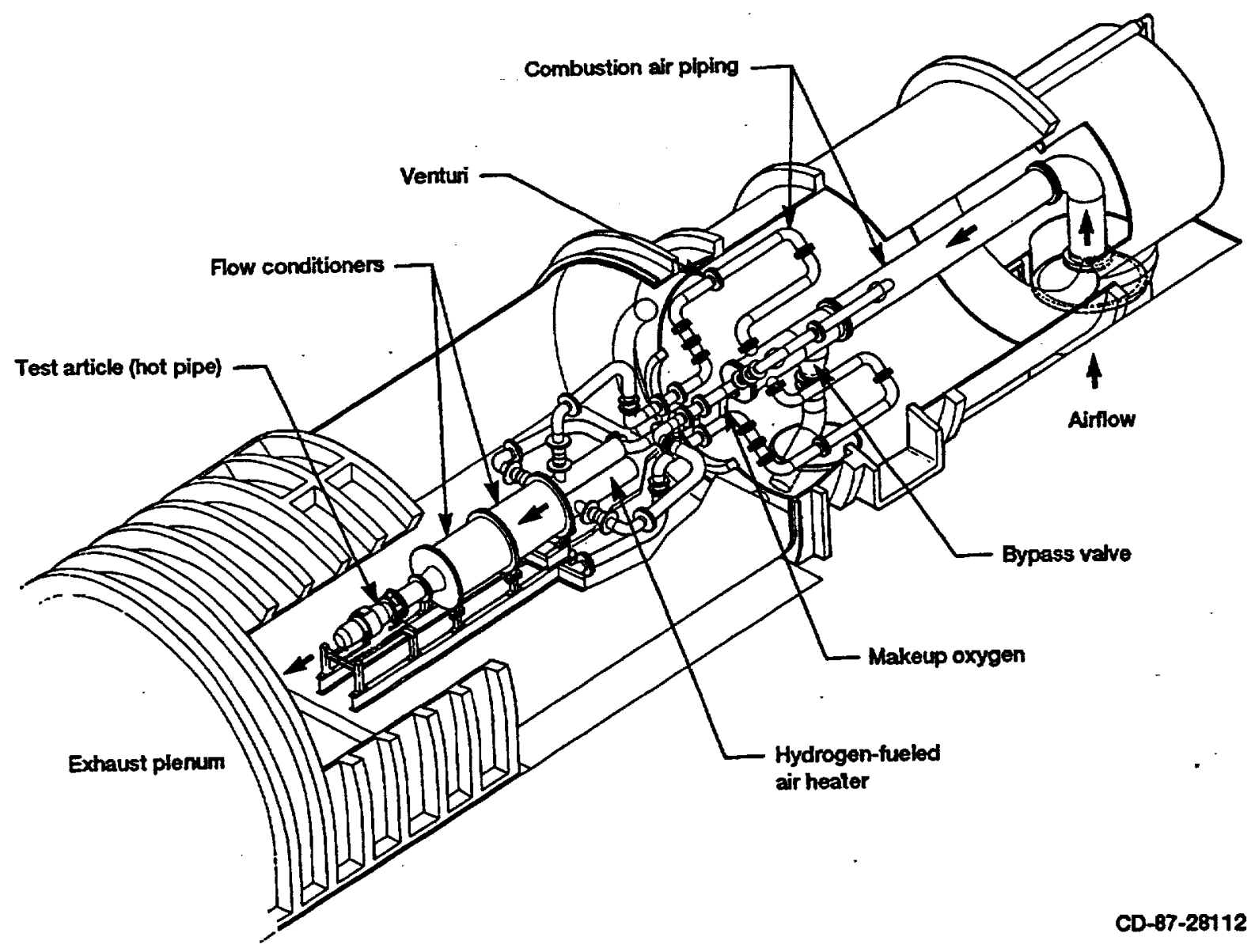

Figure 1.-PSL -4 hypersonic modifications.

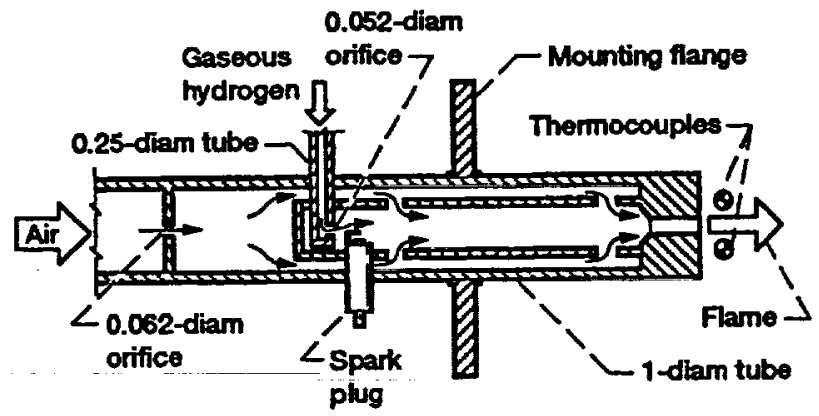

Figure 2-Schematic of hydrogen-air torch. (Dimensions are in inches.) 


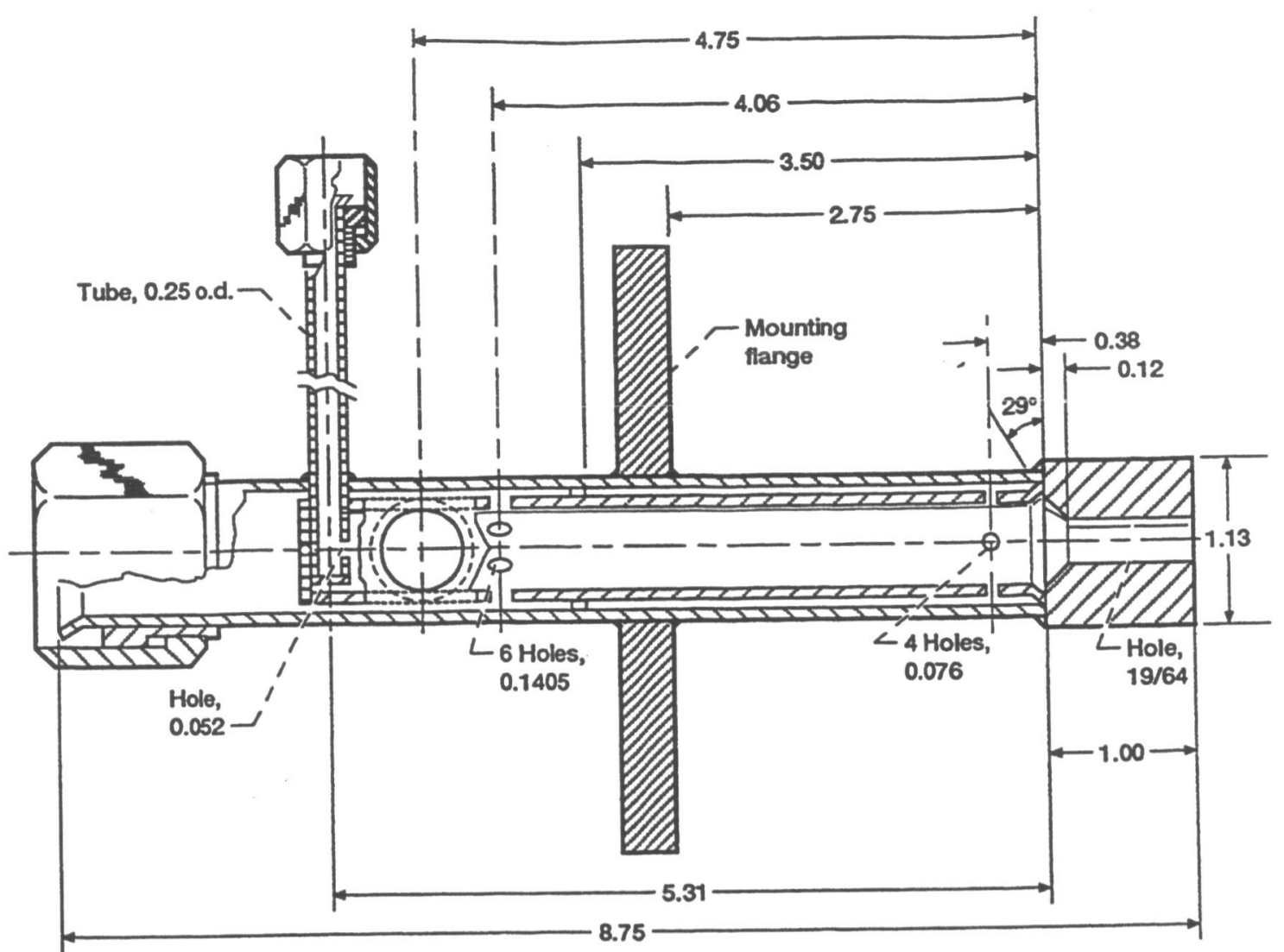

(a) Torch dimensions (in inches).

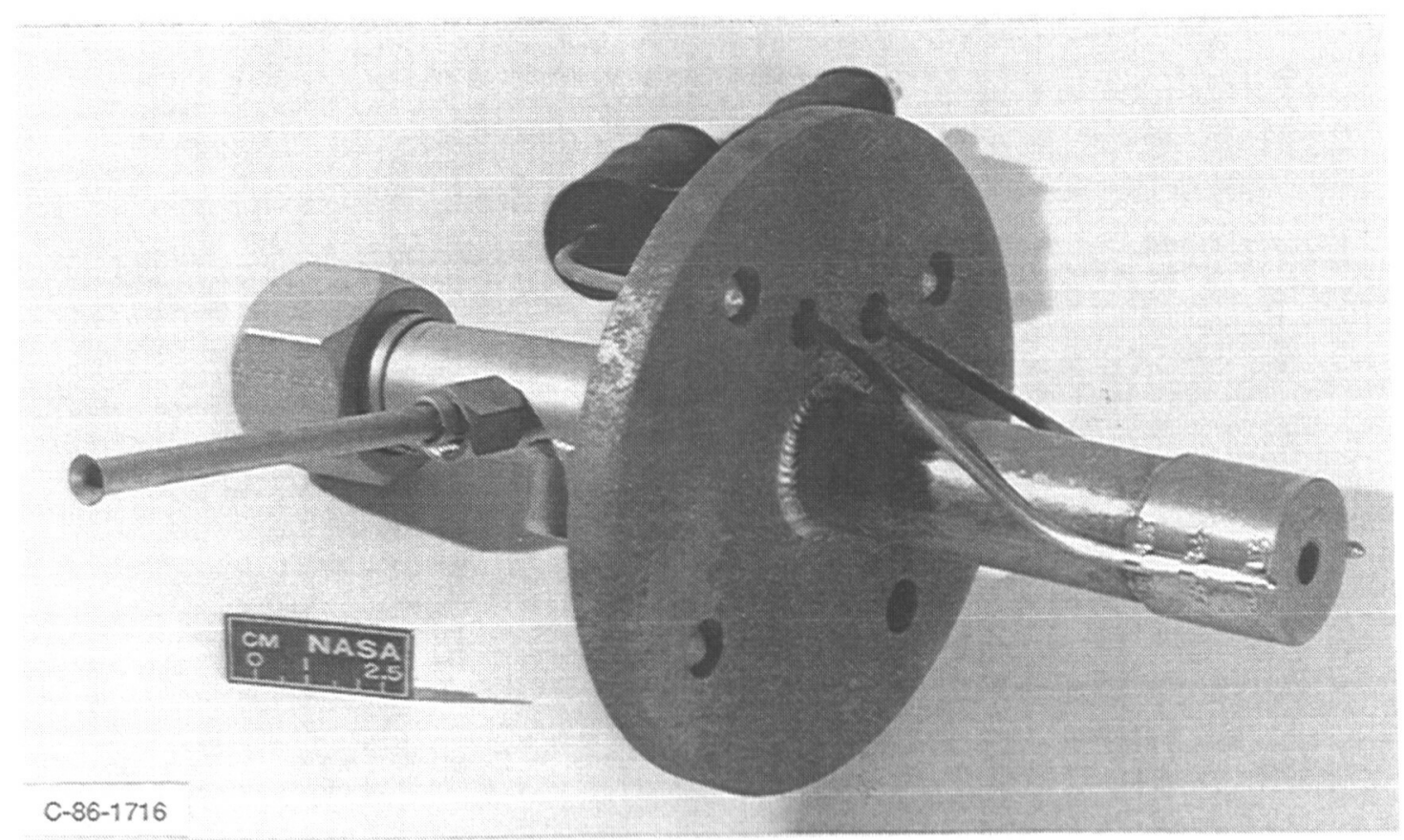

(b) Torch with thermocouples attached.

Figure 3.-RETF hydrogen-air ignition torch. 


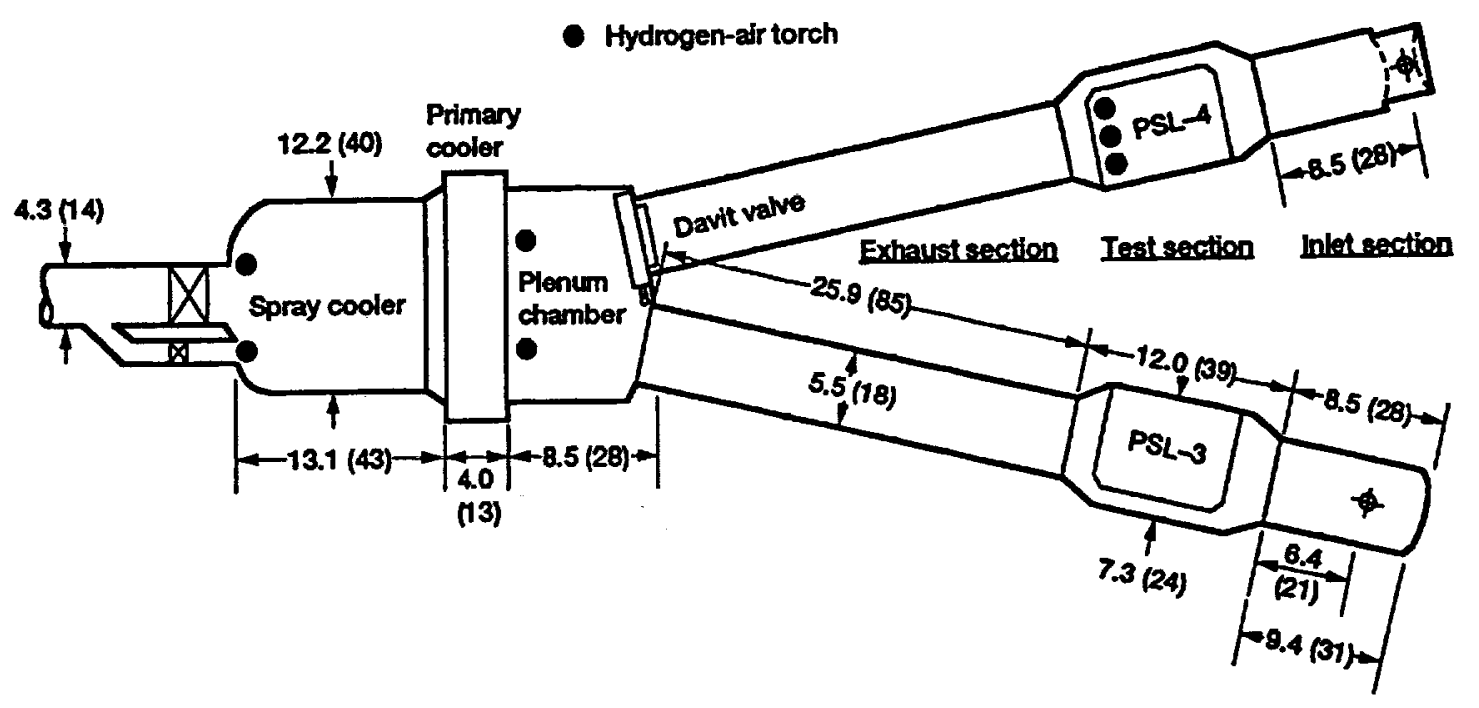

Figure 4.-PSL hydrogen-air torch locations. (Dimensions are in meters (feet).)
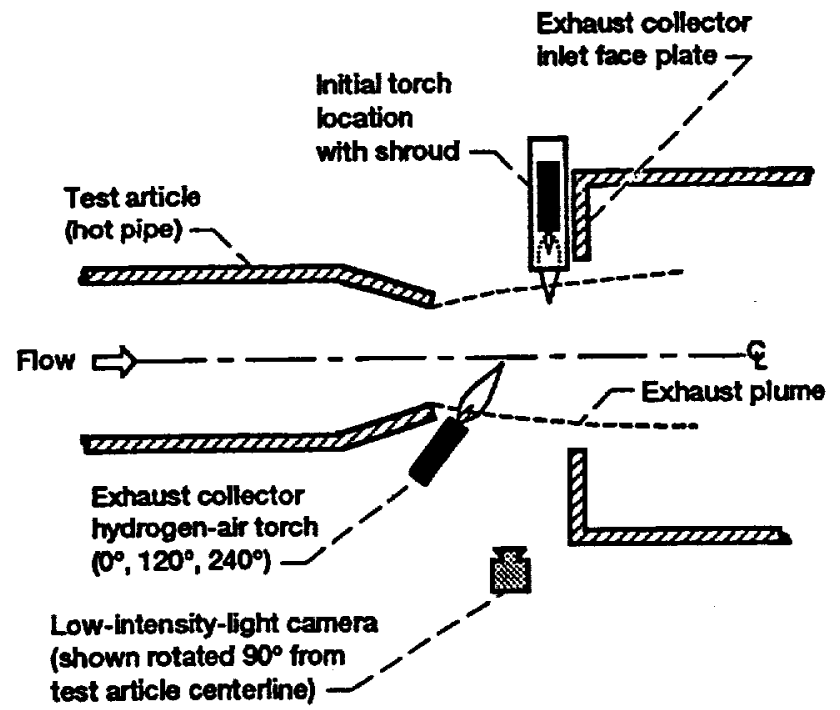

Figure 5. Elevation schematic of PSL exhaust collector hydrogen-air torch installation. 


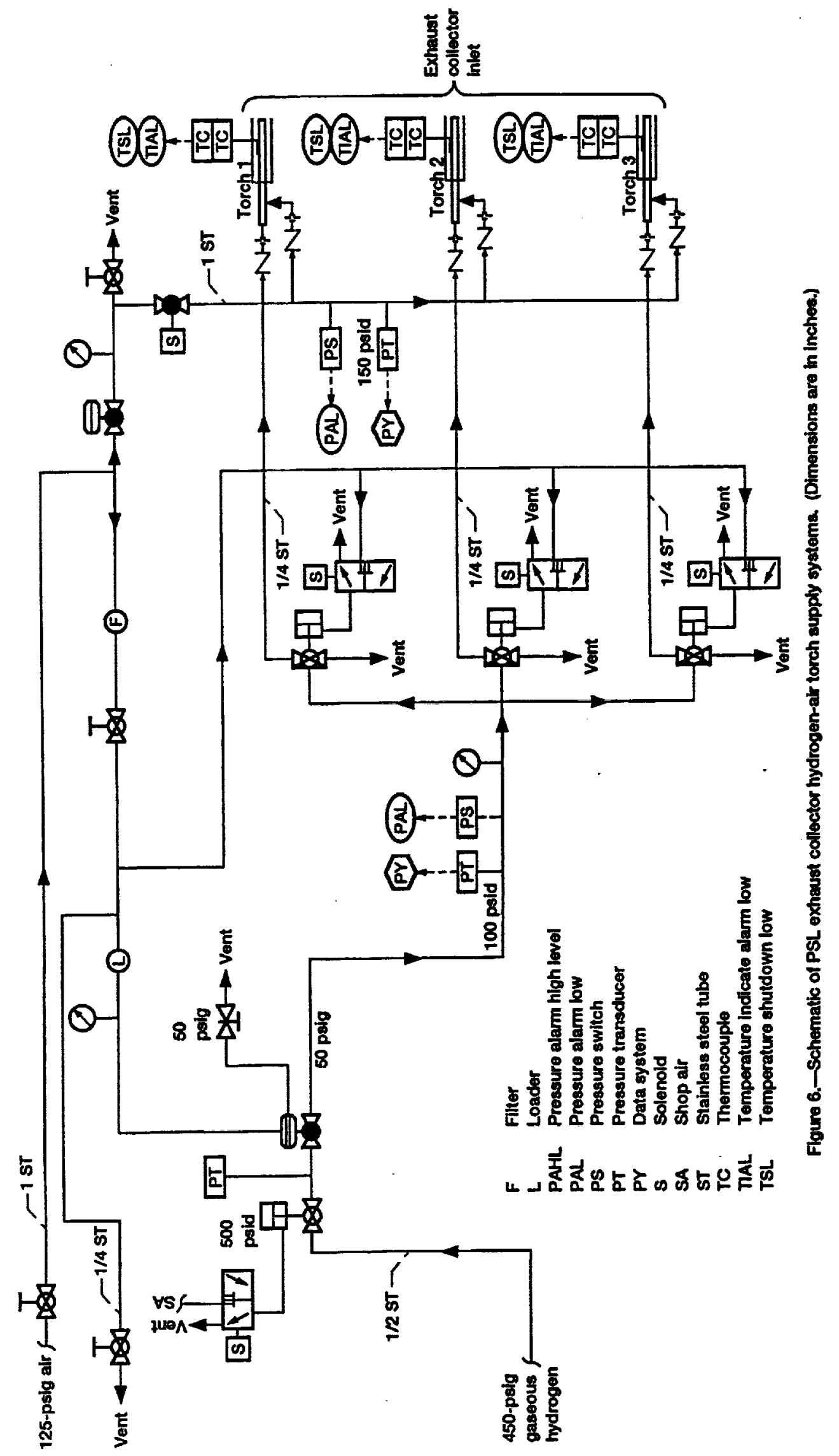




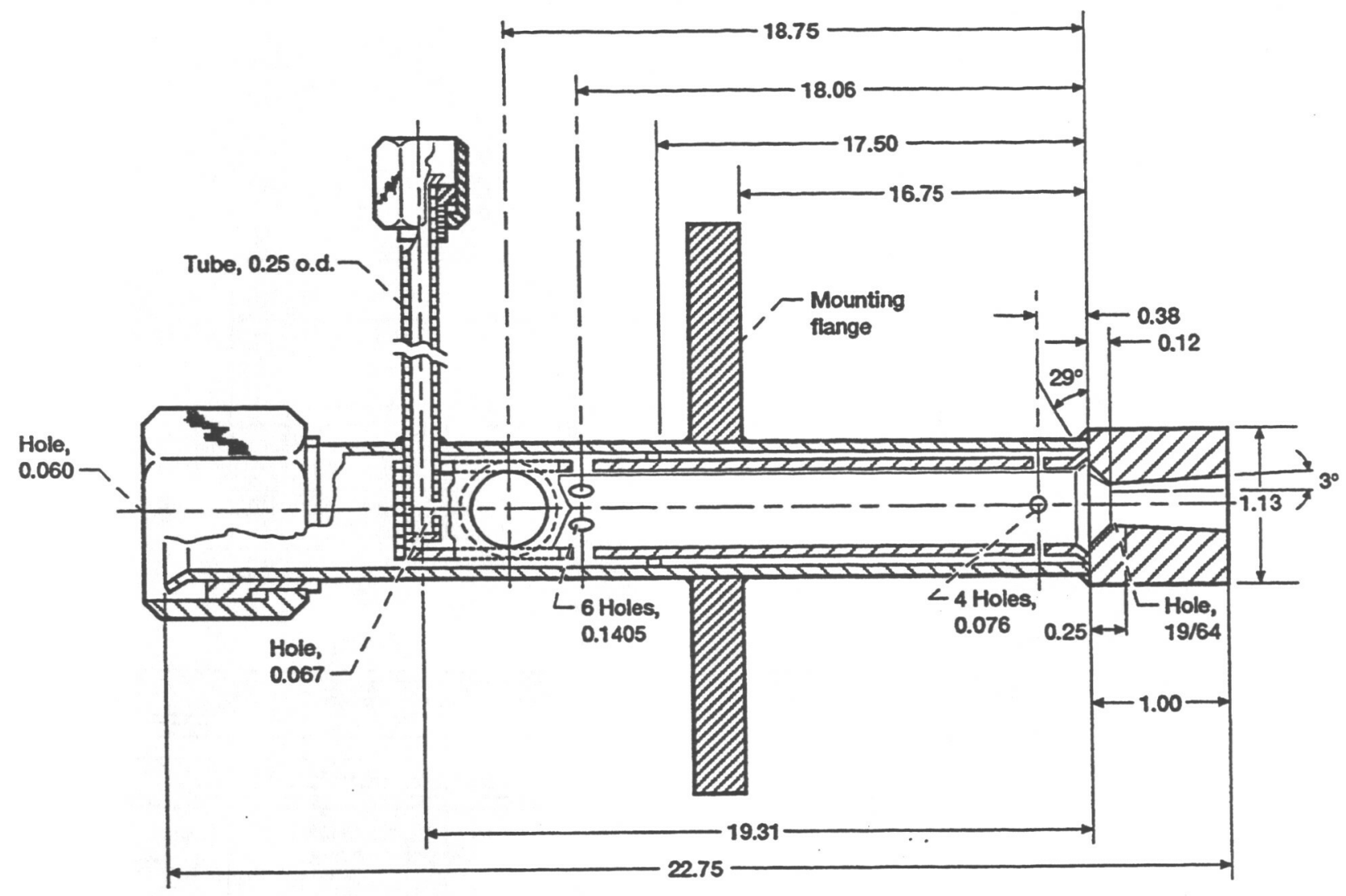

(a) Exhaust plenum torch dimensions (in inches).

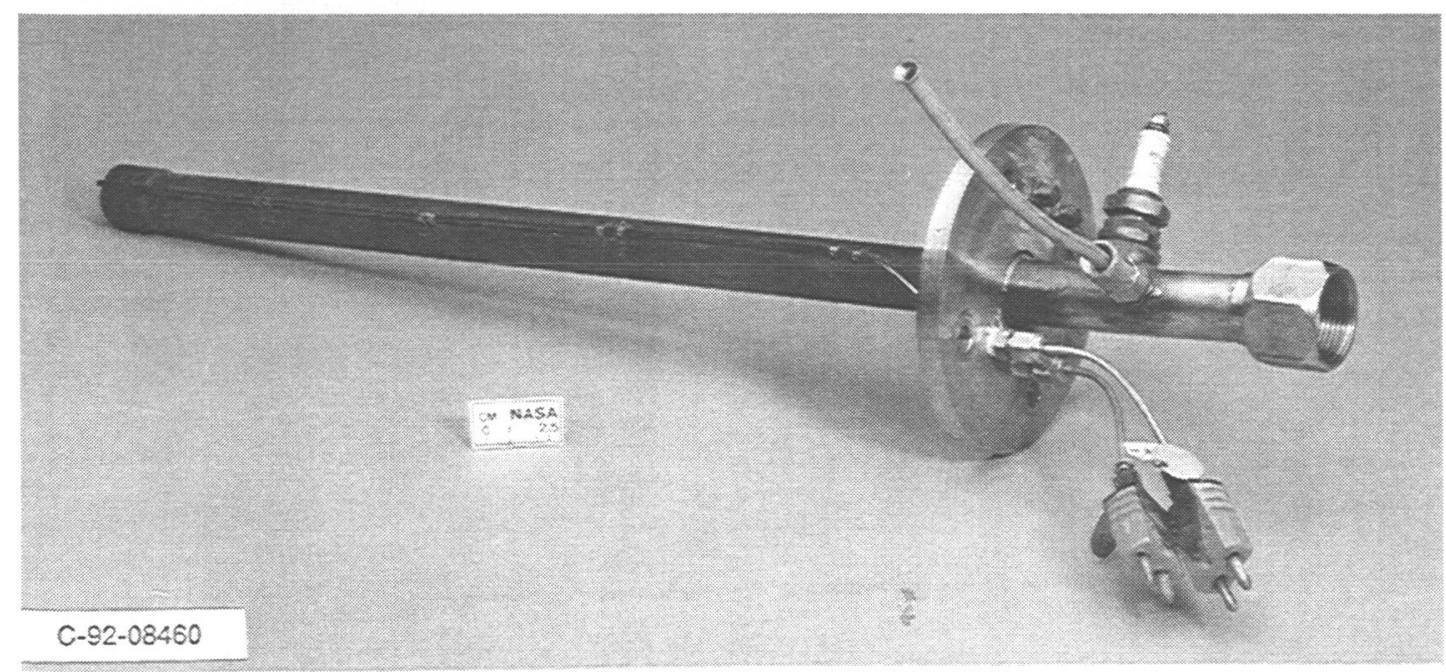

(b) Exhaust plenum torch.

Figure 7.-PSL exhaust plenum hydrogen-air ignition torch. 


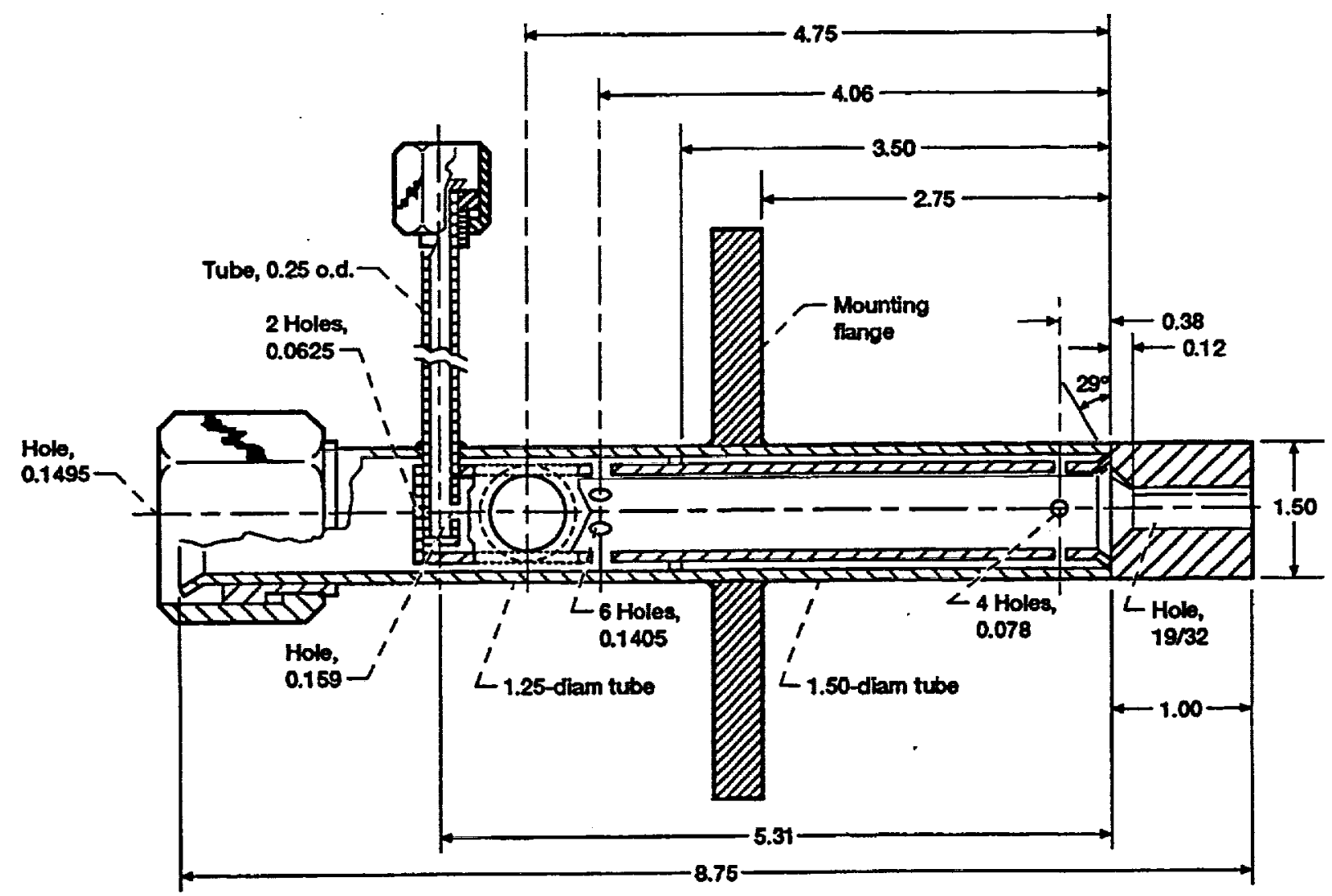

Figure 8. PSL exhaust collector hydrogen-air ignition torch with larger torch body and combustion tube and with 19/32-in. exit diameter. (Dimensions are in inches.) 


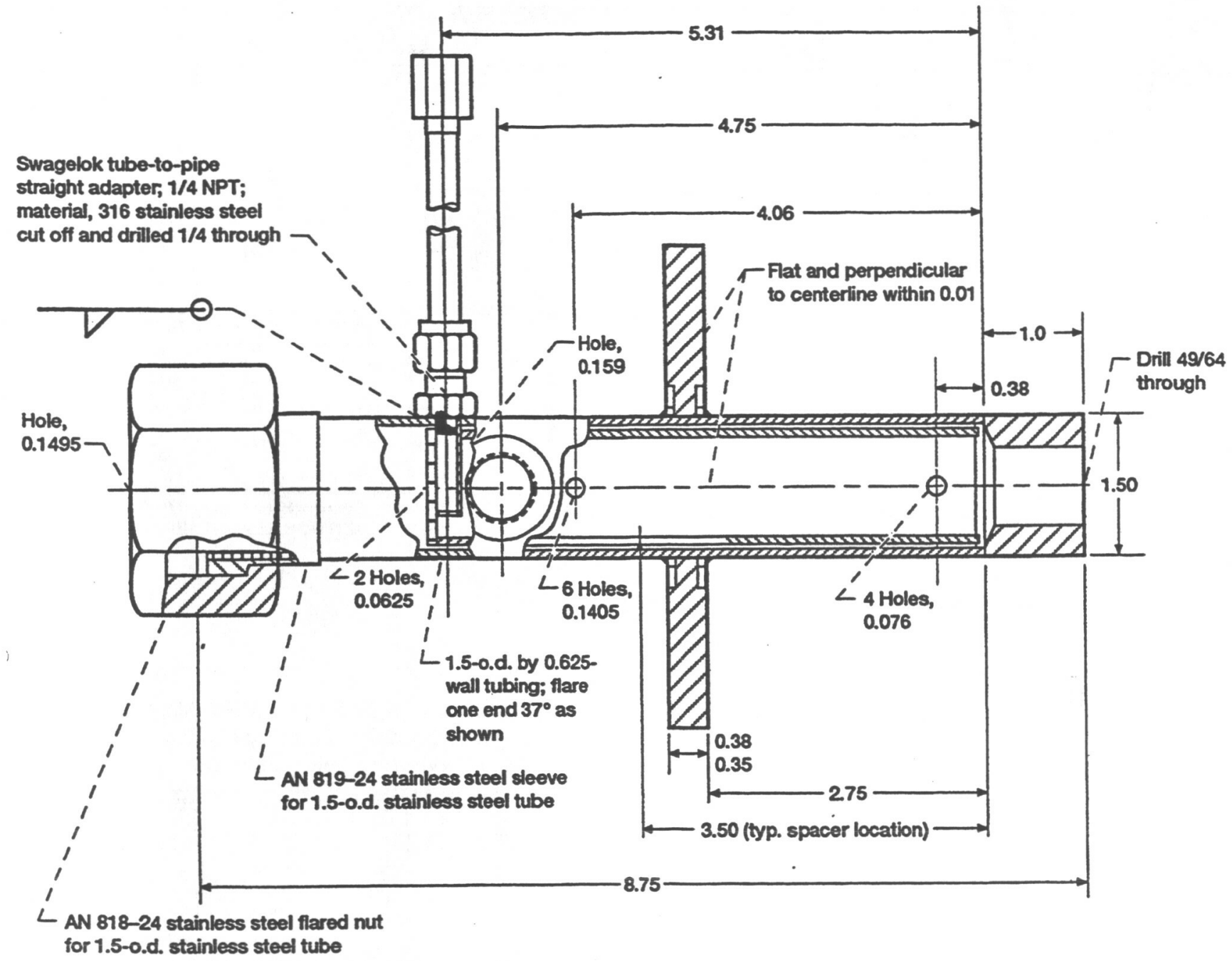

(a) Exhaust collector torch dimensions (in inches).

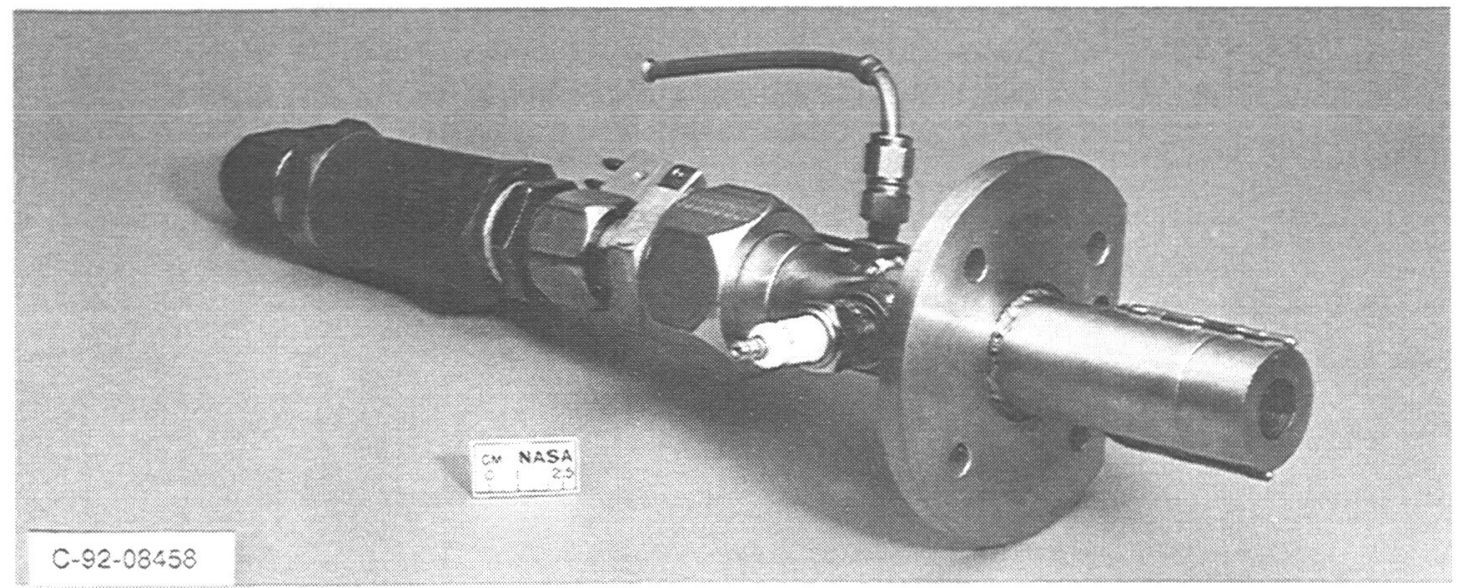

(b) Exhaust collector torch.

Figure 9.-Final PSL exhaust collector hydrogen-air ignition torch with larger torch body and combustion tube and with $49 / 64$-in. exit diameter. 
Public reporting burden for this collection of information is estimated to average 1 hour per response, including the lime lor reviewho hastructions, searching extsting data sourcess gathering and maintalning the dala needed, and completing and reviewing the collection of information. Send comments regarding this burden estimate of any other aspect of this collection of information, including suggestions for reducing this burden, to Washington Headquartors Services, Directorate hor information Operations and Reports, 1215 Jefle

\begin{tabular}{|l|c|c|} 
1. AGENCY USE ONLY (Leavo blank) & $\begin{array}{r}\text { 2. REPORT DATE } \\
\text { June } 1993\end{array}$ & $\begin{array}{r}\text { 3. REPORT TYPE AND DATES COVERED } \\
\text { Technical Memorandum }\end{array}$ \\
\hline
\end{tabular}

4. TILE AND SUBTITLE

5. FUNDING NUMBERS

Development and Use of Hydrogen-Air Torches in an Altitude Facility

6. AUTHOR(S)

WU-505-62-84

Roy A. Lottig and Gary T. Huber

7. PERforming ORganization mame(S) AND addREsS(ES)

8. PERFORMING ORGANIZATION REPORT MUMBER

National Aeronautics and Space Administration

Lewis Research Center

E-7633

Cleveland, Ohio 44135-3191

9. SPONSORINGMONITORING AGENCY NAMES(S) AND ADDRESS(ES)

10. SPONSORINGMONTORING AGENCY REPORT NUMBER

National Aeronautics and Space Administration

Washington, D.C. 20546-0001

NASA TM-106047

AIAA-93-2176

11. SUPPLEMENTARY NOTES

Prepared for the 29th Joint Propulsion Conference and Exhibit cosponsored by the AIAA, SAE, ASME, and ASEE, Monterey, California, June 28-30, 1993. Roy A. Lottig, NASA Lewis Research Center, Gary T. Huber, Sverdrup Technology, Inc., Lewis Research Center Group, 2001 Aerospace Parkway, Brook Park, Ohio 44142. Responsible person, Roy A. Lottig, (216) 433-5696.

12a. DISTRIBUTION/AVAILABILTY STATEMENT

12b. DISTRIBUTION CODE

Unclassified - Unlimited

Subject Category 09

13. ABSTRACT (Maximum 200 words)

A hydrogen-air ignition torch concept that had been used successfully in two rocket engine test facilities to consume excess hydrogen in their exhausters at atmospheric conditions was experimentally evaluated and developed in an altitude test facility at NASA Lewis Research Center. The idea was to use several of these torches in conjunction with hydrogen detectors and dilution air to prevent excess accumulation of unburned hydrogen or mixtures of hydrogen and air exceeding the sea-level lower flammability limit in the altitude facility exhaust system during hydrogen-fueled propulsion system tests. The torches were evaluated for a range of fuel-to-air ratios from 0.09 to 0.39 and for a range of exit diameters from $19 / 64$ to $49 / 64$ in. From the results of these tests a torch geometry and a fuel-to-air ratio were selected that produced a reasonably sized torch exhaust flame for consumption of unburned hydrogen at altitude pressures from sea level to 4 psia.

\begin{tabular}{|l|l|l|}
\hline 14. SUBJECT TERMS \\
Hydrogen-air; Torch \\
$\begin{array}{c}\text { 17. SECUATY CLASSIFICATION } \\
\text { OF REPORT } \\
\text { Unclassified }\end{array}$ & $\begin{array}{c}\text { 18. SECURITY CLASSIFICATION } \\
\text { OF THIS PAGE } \\
\text { Unclassified }\end{array}$ & $\begin{array}{c}\text { 19. SECURTY CLASSIFICATION } \\
\text { OF ABSTRACT } \\
\text { Unclassified }\end{array}$ \\
\hline
\end{tabular}

